\title{
Trade Openness and Tax Revenue Performance in East African Countries
}

\author{
Micah Samuel Gaalya', Bbaale Edward ${ }^{2}$, Hisali Eria ${ }^{2}$ \\ ${ }^{1}$ Commissioner General's Office, Uganda Revenue Authority, Kampala, Uganda \\ ${ }^{2}$ College of Business and Management Science, Makerere University, Kampala, Uganda \\ Email:mgaalya@gmail.com, ebbaale@bams.mak.ac.ug,ehisali@bams.mak.ac.ug
}

How to cite this paper: Gaalya, M.S., Edward, B. and Eria, H. (2017) Trade Openness and Tax Revenue Performance in East African Countries. Modern Economy, 8, 690 711. https://doi.org/10.4236/me.2017.85049

Received: March 12, 2017

Accepted: May 13, 2017

Published: May 16, 2017

Copyright (c) 2017 by authors and Scientific Research Publishing Inc. This work is licensed under the Creative Commons Attribution International License (CC BY 4.0).

http://creativecommons.org/licenses/by/4.0/

\begin{abstract}
Despite the well-known gains from trade, the effects of trade openness are a priori ambiguous. For this reason it's important to establish the effects of trade openness on different sources of government revenue for any country opening its borders to trade. This study sought to establish the effects of trade openness on different categories of taxes. A panel data cointegration technique that uses the Fully Modified Ordinally Least Squares and Dynamic Ordinally Least Squares were employed. The data are annual cross country panels of East Africa countries covering the period 1994-2012. The data were obtained from the IMF's International Finance Statistics, the African Development Bank's African Economic Outlook and the World Bank's World Development Indicators. We found that the average tariff rate used as a measure for trade openness positively influences total tax, indirect tax and trade tax while the average tariff rate squared is negative, illustrating a "Laffer effect" for the three tax categories. The relationship between trade openness and direct taxes is found to be insignificant. The policy implication is that governments of EAC countries should asymmetrically implement trade openness policies, particularly lowering the tariff rate to help in improving tax performance.
\end{abstract}

\section{Keywords}

Trade Openness, Tax Revenue Performance, EAC Countries

\section{Introduction}

The latter part of the twentieth century has been associated with substantial expansion in trade flows, capital movements as well as mobility of labour across borders. During the period world trade in goods and services has grown dramatically from about US $\$ 6.199$ trillion in 1994 to approximately US $\$ 26.02$ tril- 
lion in 2012. This reflects a growth rate of 76.1 percent [1]. For the period, world trade grew on average nearly twice as fast as world production, suggesting that countries are increasingly trading with each other. In the case of EAC countries trade in goods and services increased from about US $\$ 4.4$ billion in 1994 to approximately US $\$ 36.78$ billion in 2012 . This shows a growth rate of 88.1 percent [1]. An analysis of the growth rate suggests that EAC countries have a higher trade growth rate in contrast to the world trade. The above statistics indicates that for the period, EAC countries trade grew much faster than world trade.

Accordingly, the [2] identifies three major reasons for the growth in world trade; and these reasons are likely to continue increasing growth in trade in the medium and long term. The first reason is that improvements in the technology of transportation and communication have greatly reduced the costs of transporting goods, services as well as factors of production. Additionally, the increasing convergence of tastes and preference of individuals and societies has increased demand for goods and services across countries. Lastly, the global economic cooperation has led to trade openness or reduction and removal of barriers to free trade. These three reasons have influenced the growth in world trade [2]. In this paper we discuss the influence of trade openness or reduction and removal of barriers to free trade on EAC countries.

The increasing prominence of trade openness is motivated by four major gains; however, there are considerable overlaps among them [2]. These gains come from unilateral trade openness policies as well as from trade openness policies that take place through regional and multilateral negotiations. The five major gains from trade openness are presented below; to begin with, trade openness allows countries to export those goods and services that they make efficiently and to import those goods and services that they make inefficiently. Next, trade openness results in lower prices, enabling an increase in real income which increases consumer and producer welfare. In the same way, trade openness leads to gains in total factor productivity i.e., freer trade exposes countries to new production technologies that foster higher productivity at both firm and industry level. Lastly, trade openness enables low income countries to raise their income levels towards high income countries [3] and [4]. These four factors have influenced the increase in trade openness across countries.

Theoretically, the influence of trade openness on imports and revenue performance is considered to be an indirect outcome. This indirect outcome is derived from the response of consumption and production decisions to price changes, of which the price changes are triggered by trade reforms [5] [6] [7]. For example, a reduction in import tariffs is likely to influence imports and revenue performance depending on the elasticity of import demand and price elasticity of supply for import substitutes i.e., if the demand for imports is inelastic it's likely that import volumes and revenue performance will remain unchanged irrespective of the changes in import tariffs and prices. On the other hand, if the demand for imports is elastic it's possible that import volumes and revenue performance will increase owing to changes in import tariffs and prices. 
This theoretical relationship has been examined by [4] [7]-[12] among others. This literature can be summarized into two groups, the first group shows that removal of barriers to free trade increases revenue performance while the second group shows that removal of barriers to free trade leads to a decline in revenue performance.

An example of studies in the first group are presented below; Firstly, [3] using panel data on developing countries concludes that structural factors such as GDP per capita, share of agriculture to GDP, trade openness and foreign aid significantly increase revenue performance in developing countries. The study shows that trade openness has a strong positive relationship with total revenue performance. However the inadequacy of this study is that it focusses on total revenue performance and ignores the influence of trade openness on disaggregated categories of taxes such as direct and indirect taxes.

Secondly, a study by [13] using a set of factors that influence revenue performance suggest that revenue performance is higher in more open and less agricultural dependent economies that are less populous and peaceful. Overall this study shows that trade openness has a positive relationship with trade taxes and GDP per capita.

On the other hand studies in the second group which shows that removal of barriers to free trade increases imports but leads to a decline in revenue performance. These include; In the first place, [14] examining the relationship between tariff reform and trade taxes in Uganda shows that exchange rate depreciation has had a pass through effect to the domestic market price of imports and this increases trade taxes in the short run but reduces trade taxes in the long run. This study predicts that trade openness will to some extent decreases revenue performance. The shortcoming of this study is that it does not consider other key categories of taxes that influence overall revenue performance such as direct, indirect and total revenues.

Next, [10] examining the fiscal effects of tariff reduction for Caribbean community concludes that Caribbean countries have experienced revenue shortfalls as a consequence of trade openness. Similarly [15] examining the fiscal effects of tariff reforms on Uganda's trade with EAC countries concludes that Uganda has experienced revenue shortfalls as a result of reducing its import tariff rates. However the shortcoming of this study is that it only considers effects of trade openness on import tariff and it does not consider other key categories of taxes that influence overall revenue performance such as direct and indirect tax revenues. Also, [19] using a panel of 117 countries over a 32-year period, examine [16] theory of tax structure development which states that as countries develop they progressively change their tax structure to adopt it to the changes in economic structure. More specifically the countries tend to replace trade revenue with domestically based revenues. In relation to this theory [17] show that low income countries have not recovered from domestic taxes the revenues they have lost from trade openness. Nonetheless the study shows that the replacement of trade taxes with domestic taxes has become higher than previous studies 
have suggested.

In addition, [11] examining the argument that trade openness depresses the revenue performance in developing countries show that low income countries and upper middle income countries have experienced declining revenues on account of trade openness. They conclude that trade openness leads to falling direct and trade revenues and that the structural characteristic of low income and developing countries have been significant in explaining the decline in revenue performance. Lastly, [18] examining the relationship between trade openness and revenue performance in sub-Saharan Africa, conclude that trade openness raises overall taxes in French colonies of Africa (CFA franc countries), though the disaggregated tax outcome suggest that trade openness raises trade taxes but lowers indirect taxes. To sum it all up, from the above literature, it's clear that trade openness affects revenue performance, the effects are either negative or positive depending on the economic structures of an economy or region.

In the case of EAC countries despite implementing trade openness reforms, hitherto there are no studies that investigated the effects of trade openness on different categories of taxes. Studies by [13] and [14] have only investigated effects of trade openness on trade taxes and do not consider effects of trade openness on other key categories of taxes.

Furthermore, according to [8] the average tariff rate is taken to indicate the level of trade openness for an economy, as such a decline in the average tariff rate is taken to indicate greater trade openness while an increase in the average tariff rate is taken to indicate lower trade openness. From the Figure 1 we conclude that EAC countries have experienced a reduction in tariff rates which reflects an increase in the level of trade openness.

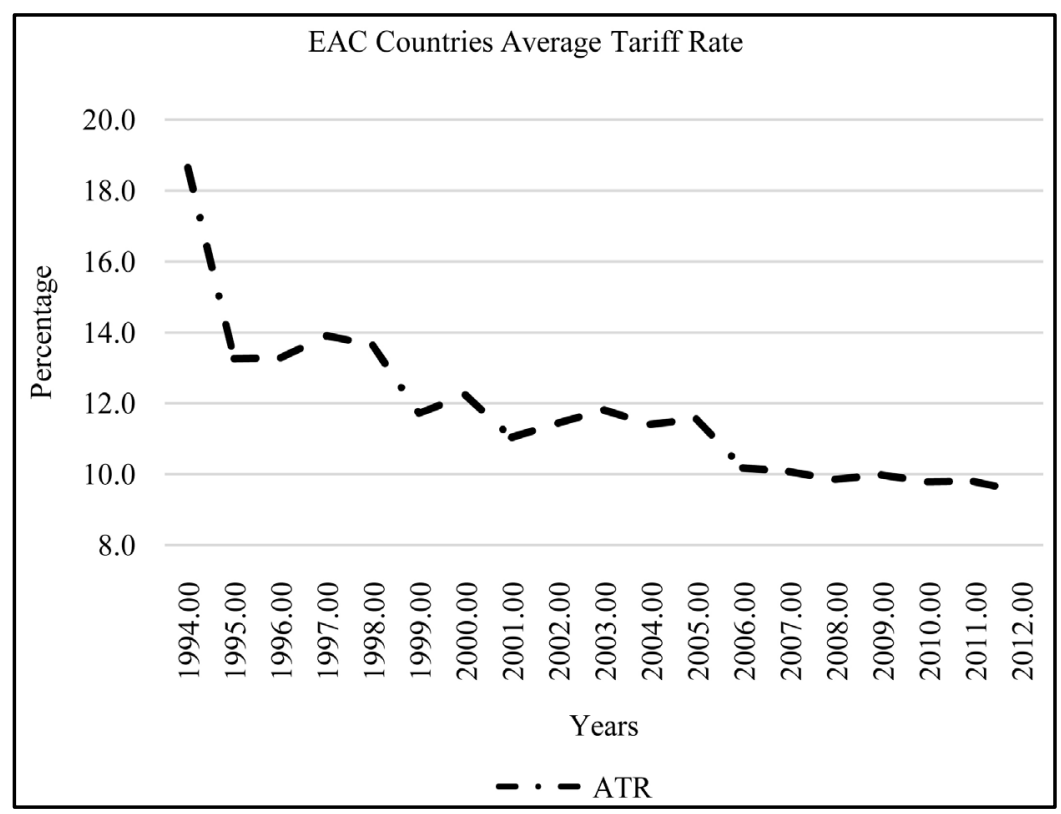

Figure 1. EAC countries average tariff rate. Source: World development indicators, world bank, April 2014. 
Example of trade openness reforms implemented in EAC countries include; implementation of tariff reforms under the World Trade Organization and General Agreement on Tariffs and Trade (GATT), tariff reforms under the IMF and World Bank Structural Adjustment Program and tariff reforms under the EAC customs union protocol [2]. These reforms have involved the reduction of tariff and non-tariff barriers across EAC countries.

Correspondingly, according to Figure 2 the revenue performance measured by the tax to GDP ratio shows that for the period 1994 to 2012, revenue increased however, despite the increase in revenue performance, the EAC country's average total tax to GDP ratio that stands at 12.52 percent is less than the sub-Saharan Africa average total tax to GDP ratio of 16.1 percent [15]. The lower EAC country's average total tax to GDP ratio appears to imply that EAC countries are experiencing low revenue performance as compared to other subSaharan African countries.

From economic theory and literature, it appears that the lower tax performance and higher levels of import demand could be driven by increased levels of trade openness. Therefore this study attempts to answer the question how does trade openness affect revenue performance for the EAC countries?

\section{Statement of the Problem}

It's argued that the reduction or removal of barrier to free trade, such as import tariffs lowers import prices but also reduces an array of taxes charged at importation. The gains from removal of barriers to free trade are expected to increase domestic output through the use of better imported skills and technology to foster high productivity at both firm and industrial level; thereby lowering import for certain categories of imports but also increasing domestic productions and revenue performance.

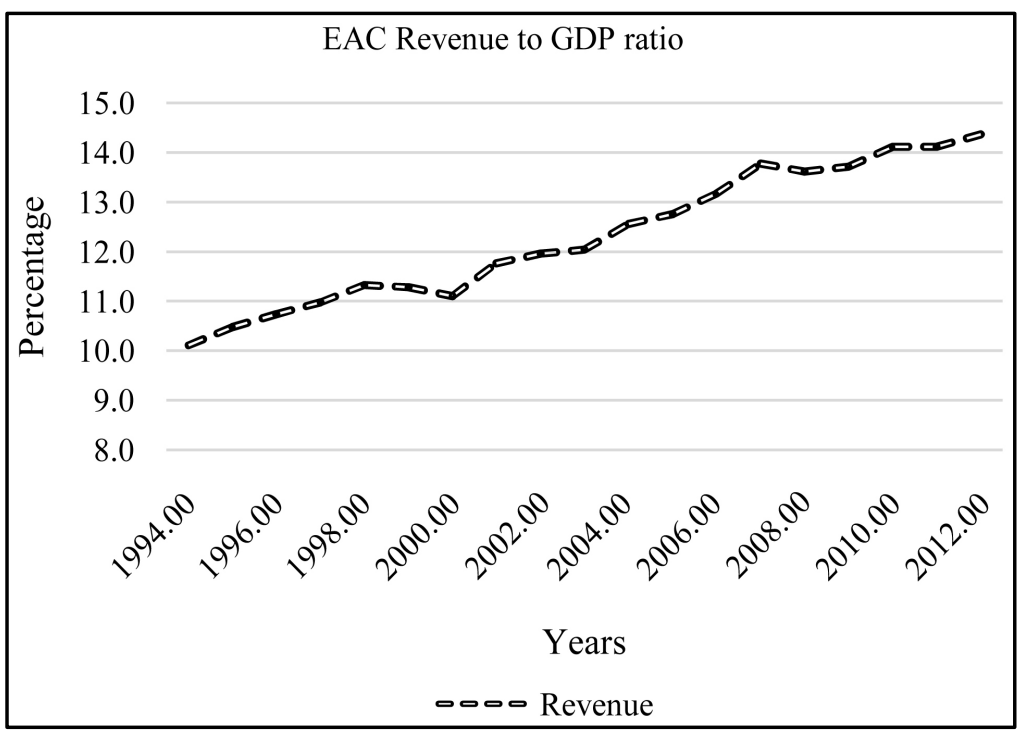

Figure 2. EAC Revenue to GDP ratio. Source: World Development Indicators, World Bank, April 2014. 
In the case of EAC countries, despite implementing trade openness reforms the revenue performance measured by the tax to GDP ratio shows that EAC countries are experiencing lower revenue performance as compared to the average sub Saharan Africa revenue performance. This is expected to cause limited funding for government, if revenue performance are not improved.

If the low tax performance is not improved, EAC countries will have to review their trade openness policies in order to avoid problems associated with limited funding for government. Thus, it's imperative that evidence regarding the influence of trade openness on tax performance is provided given the strategic importance of taxes to development of EAC countries.

\section{Literature Review}

\subsection{Literature on Direct Taxes}

The literature on tax performance indicates that direct taxes are composed of personal income taxes, corporate income taxes, rental income taxes, withholding taxes and capital gains taxes. The revenue from these tax handles are defined as income taxes or direct taxes [14].

The theoretical linkage between trade openness and direct taxes is likely to be through price change or economic growth. This relationship has been examined by a number of studies such as [4] [8] [16] among others. Amongst these studies [8] points out that trade openness is related to high levels of economic growth and that countries that have opened up to trade have increased their levels of growth and income taxes. Another study by [4] investigates the effects of trade openness on income taxes by applying the gravity model. They find that trade openness substantially raises income. They predict that since a one percent increase in the shares of imports and exports in GDP leads to a one-half to two percent increase in income per person. This implies that trade openness which induces higher volumes of trade is associated with higher incomes.

A study by [15] uses a gravity model and shows that trade openness increases trade flows, which further supports the hypothesis that trade openness leads to an increase in trade volumes and economic growth. Additionally the growth in the economy is likely to have a direct impact on income taxes, this happens when higher per capita income leads to widening of the tax base for income taxes. For example, [16] provides a solid theory supporting a causal relationship between per capita income and tax level in his tax base and tax handle theory. He states that an increase in per capita income raises the size of public sector which in turn increases a country's tax base and taxable capacity. Reference [17] and [18] demonstrates the association between economic growth and tax by using regression analysis and found that overall tax is positively influenced by the level of per capita income. Although the correlation is not strong, he finds that per capita income has a positive impact on personal income $\operatorname{tax}$. 
In another study by [7] he points out that income taxes may be difficult to mobilize in low income countries because of the high administrative costs and other structural constraints. In low income countries, income taxes are relatively easy to evade because most developing countries generally have weak penalty on tax evasion. There also other structural challenges that increase the ease of tax evasion. Therefore, in developing and less developed countries, income tax is usually levied on wages of public sector employees, foreign corporations and a few small and medium enterprise [7]. These factors depress the income tax base, resulting in a narrower base in developing countries than in developed countries, and hence lower tax from this tax category irrespective of trade openness efforts.

\subsection{Literature on Indirect Taxes}

The literature on indirect taxes shows that indirect taxes are composed of Value Added Tax (VAT) or Commercial Transaction Levy and Sales tax as well as Excise tax [14]. These taxes are considered to be a good solution for offsetting the decrease in tax arising from changes in the international trade tax regime because they have a broader tax base as compared to income taxes [15].

According to [15] the relationship between trade openness and consumption tax is more complicated to assess as compared to the relationship between trade openness and income taxes. This is because the effects of trade openness on indirect taxes depends on many factors such as the price elasticity of demand for imports and the price elasticity of supply of import substitutes [15]. For example, when import tariffs are reduced, the relative price of imports to import substitutes may also decrease, which may make domestic consumers switch to consumption of more imports. Consequently this may lead to a decrease in taxes collected from domestically produced import substitutes and an increase in taxes from imports.

The effect of trade openness on indirect tax can also be viewed through its impact on economic growth. For example, the assumption that tax bases grow as economic growth proceeds also true for the consumption tax. The growth in the economy is also related to the growth in the consumption tax base [15]. Therefore consumers should have more income in their hand as the economy grows, which means that there is higher purchasing power and higher demand for domestic consumption.

However, surprisingly, the results shown in [7] state that there is no correlation between consumption taxes and income per capita. Despite the result in this study, [10] shows that a countries size plays an important role in determining the domestic consumption tax. Furthermore, [15] show that consumption taxes are more significant tax source in the bigger countries than in the smaller countries. In the same way the amount of consumption taxes collected depends directly on the domestic consumption, that is, larger countries tend to have a high population and a large domestic market whereas smaller countries seem to have 
a smaller population and their size of domestic market is smaller. As a result, switching sources of tax from trade tax to a broad-based consumption tax, although applicable for developed countries, may cause fiscal problems for developing and less developed countries which have smaller market sizes. There for the impact of trade openness ought to be evaluated.

\subsection{Literature on Trade Taxes}

According to literature trade taxes are composed of import and export taxes as well as a broad array of taxes charged on goods and services at the point of import or export [14]. Trade tax is thought to decline after countries open up their trade tax regime. Economic theory points out that the reduction in import tariff often leads to a decline in trade tax especially for small open economies [3]. A number of empirical studies have been undertaken to assess these effects, most of the studies have used tax share in GDP as the dependent variable with different combinations of explanatory variables. For example, [10] investigates the effects of trade openness on trade tax in the Caribbean community. The study finds evidence that trade openness in the Caribbean countries lead to a reduction in trade tax.

Reference [3] studies the principal determinants of tax performance across developing countries by using a broad dataset of 105 countries over 25 years. In his study he noted that per capita GDP, agriculture share in GDP, trade openness, foreign aid, corruption, political stability, the share of direct and indirect taxes are significant in determining tax performance. The paper concluded that tax collections are low in countries, which heavily depend upon taxing goods and services, while countries that depend on income taxes have high outturn of tax. However for countries that have opened up there trade regimes, trade taxes appear to have declined.

Similarly [8] proposes that if trade openness is accompanied with a reduction in tariff dispersion, then tax revenue may increase. The rationale is that a reduction in the dispersion of tariff is often done by lowering the higher tariff and increasing lower tariff in order to obtain average values. The study further proposes that if the initial tariff rates are high, then tariff reduction may lead to an increase in tax revenue since price elasticities of demand and supply are not constant over the entire range of prices.

The above effect can be illustrated by a Laffer curve, which shows the relationship between tax revenue and tariff restrictions (Figure 3 ). The illustrations shows that when the initial tariff rate is prohibitively high, the trade volumes are likely to be severely bottled-up and tax will be low. As such reducing tariffs will lead to a substantial increase in trade volumes and a decrease in the incentive to evade taxes. However, if there is a further tariff reduction after trade is fairly liberalized at the tax maximizing rate the increase in trade volume will not be large enough to offset the lower tariffs and now the direct effect of tariff reduction will result in the loss of taxes. As a result, overall tariff revenue will decrease [8] [19] [20] [21]. 


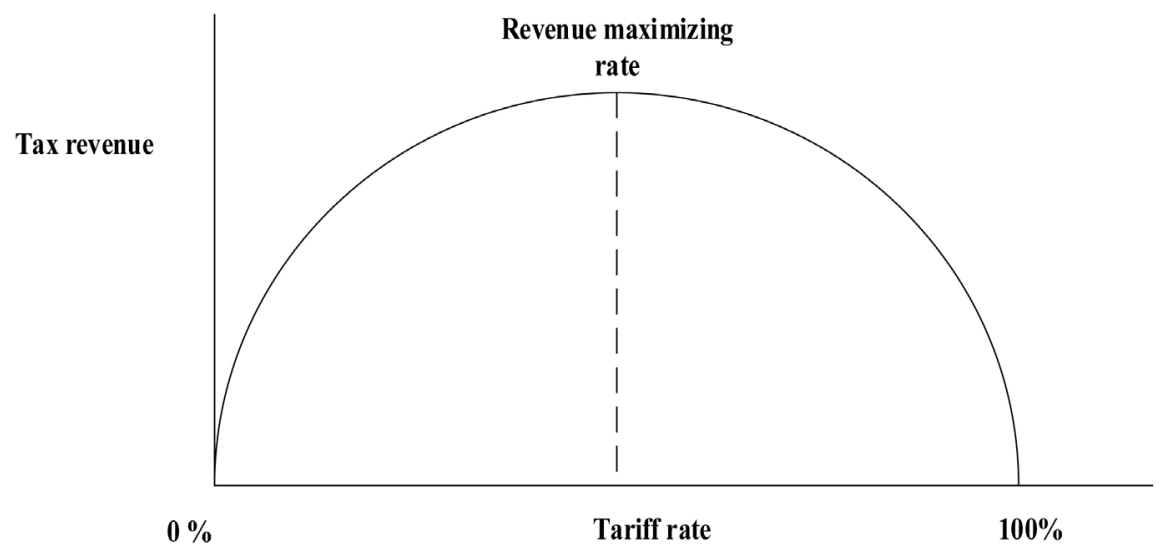

Figure 3. Laffer curve. Source; Laffer (2004).

Economic theory proposes that the higher the tariffs, the higher the tax evasion since evasion leads to high marginal benefit for tax payers. Reference [22] shows that a one percent increase in tariff rates is associated with a three percent increase in tax evasion. The assumption is that tariff reduction raises the costs for tax evaders and hence lowers the level of tax evasion. Therefore reduction in tariff brings an increase in tax revenue [23].

Among the studies conducted on trade tax performance in the EAC is a study by [24]. The study examines the relationship between tariff reforms and customs revenue by explicitly capturing the institutional features of decision making in Uganda. The study uses the Johansen multivariate approach and Error Correction Model to establish the long-run and short run relationship between trade openness and trade tax. The results show that exchange rate depreciation has pass through effects to the domestic market price of imports which reduces trade tax to GDP ratio in the long-run, though it increases trade tax in the short term.

\subsection{Synthesis of the Literature}

The section provides a synthesis of literature on studies investigating effects of trade openness on tax revenue. This literature can be summarized into two groups, the first group shows that removal of barriers to free trade increases revenue performance [3] and [13], while the second group shows that removal of barriers to free trade leads to a decline in revenue performance [10] [15] [17] [24] among others. The studies have used the following data estimation techniques to estimate tax revenue functions i.e., Error Correction Model, Vector Error Correction Models, Auto Regressive Distributed Lag models, Fixed and Random Effects models as well as the General Method of Moments.

The literature only examines the influence of trade openness on trade taxes but does not examine the influence of trade openness on other tax categories such as direct and indirect taxes for EAC countries. As such, despite implementing trade openness reforms in the EAC countries, hitherto there are no studies that investigated the effects of trade openness on direct and indirect 
taxes for EAC countries. This study contributes to trade literature by undertaking a study that estimates the effects of trade openness on different tax categories in the EAC countries.

\section{Methodology for Estimating Tax Revenue Functions}

\subsection{Model Specifications}

Analysis of tax literature by [3] [11] [25] [26] [27] [28] reveals that studies looking at tax performance have used a variety of methods. The most commonly used approach is the behavioral approach. The approach was proposed by [27] and [29] to measure tax performance. The approach regresses the tax to GDP ratio on a set of variables that serve as proxies for a country's tax handles. In a functional form, the tax function is presented below;

$$
T_{t} / Y_{t}=f\left(V_{t}\right)
$$

where,

$T_{t}=$ tax performance.

$Y_{t}=$ real GDP.

$T_{t} / Y_{t}=$ tax to GDP ratio.

$V_{t}=$ vector of tax handles.

$t=$ is a time subscript.

We rewrite Equation (3.1) into an econometric form i.e.

$$
T_{t} / Y_{t}=\beta_{1}+\beta_{2} V_{t}+\varepsilon_{t}
$$

where;

$\beta_{(1 \text { and 2) }}=$ are coefficients for the tax performance variables.

$\varepsilon_{t}=$ is the error term.

Tax performance is considered as an endogenous variable while the vector of tax handles are considered as exogenous variables. Equation (3.2) is transformed into Equation (3.3) where the endogenous and exogenous variables are introduced. Hence, total tax, indirect, direct and trade tax functions can be expressed as follows:

$$
\begin{aligned}
T_{t} / Y_{t}= & \beta_{0}+\beta_{1} \text { Urban }_{t}+\beta_{2} \text { GDP }_{t}+\beta_{3} \text { Aid }_{t}+\beta_{4} \text { REER }_{t} \\
& +\beta_{5} \text { Inflation }_{t}+\beta_{6} \text { Agric }_{t}++\beta_{7} \text { Debt }_{t}+\varepsilon_{t}
\end{aligned}
$$

where;

$T_{t} / Y_{t}=$ Total tax, direct, indirect and trade tax to GDP ratio.

$U_{r b a n}=$ Share of urban population to the total population.

$G D P_{t}=$ GDP per capita.

$\operatorname{Aid}_{t}=$ Aid per capita.

$R E E R_{t}=$ Real effective exchange rate.

Inflation $_{t}=$ Consumer Price Index.

Agric $_{t}=$ Share of agricultural sector to GDP.

Debt $_{t}=$ Debt stock as a percentage of Gross National Income.

$t=$ is a time subscript.

$\varepsilon_{t}=$ is the error term. 
To establish the effects of trade openness on different categories of taxes for EAC countries, we convert model to a panel estimation and also introduce the average tariff rate alongside other control variables. These variables are drawn from literature as proposed by [3] [11] [25] [26] [27] [28] among others.

Based on the literature the average tariff rate, average tariff rate squared, government effectiveness, rule of law, regulatory quality and control of corruption are introduced into the tax function in Equation (3.3). Therefore Equation (3.3) becomes Equation (3.4) which is the tax function that establishes the effects of trade openness for EAC countries. The equation is expressed as follows:

$$
\begin{aligned}
T_{i t} / Y_{i t}= & \beta_{0}+\beta_{1} \text { Urban }_{i t}+\beta_{2} G D P_{i t}+\beta_{3} \text { Aid }_{i t}+\beta_{4} R E E R_{i t}+\beta_{5} \text { Inflation }_{i t} \\
& +\beta_{6} \text { Agric }_{i t}+\beta_{7} \operatorname{Debt}_{i t}+\beta_{8} A T R_{i t}+\beta_{9} A^{2} R_{i t}^{2}+\beta_{10} G E_{t} \\
& +\beta_{11} L A W_{i t}+\beta_{12} R Q_{i t}+\beta_{13} C C_{i t}+\varepsilon_{i t}
\end{aligned}
$$

where,

$T_{i t} / Y_{\text {it }}=$ Total tax, direct, indirect and trade tax to GDP ratio.

$U_{r b a n}$ it $=$ Share of urban population to total population.

$G D P_{i t}=$ GDP per capita.

Aid $_{i t}=$ Aid per capita.

Exch $_{i t}=$ Real effective exchange rate.

Inflation $_{i t}=$ Consumer Price Index.

Agric $_{i t}=$ Share of agricultural sector to GDP.

$D e b t_{i t}=$ Debt stock as a percentage of Gross National Income.

$G E_{i t}=$ Government effectiveness.

$L A W_{i t}=$ Rule of law.

$R Q_{i t}=$ Regulatory quality.

$C C_{i t}=$ Control of corruption.

$\varepsilon_{i t}=$ is the error term.

$t=$ is a time subscript.

$i=1,2,3,4,5$.

\subsection{Data Type and Sources}

The study employs a cross country panel which includes the following countries; Burundi, Kenya, Rwanda, Tanzania and Uganda. Data on the total tax to GDP, indirect tax to GDP, direct tax to GDP and trade tax to GDP are obtained from the Africa Economic Outlook, Statistical Annex, however the data range is limited only to period since the year 1994 which became the base year for this research. Data on share of urban population to the total population, average tariff rate, debt stock, share of agriculture sector to GDP, inflation, real effective exchange rate and foreign aid are obtained from the World Bank's World Development Indicators (WDI). Data on political stability, government effectiveness, regulatory quality and rule of law are obtained from the World Bank's Worldwide Governance Indicators (Table 1).

The use of panel data offers several advantages in econometric analysis, first, panel data contains more degrees of freedom and more sample variability, hence 
Table 1. Description of the data set used in tax models.

\begin{tabular}{|c|c|}
\hline Variable & Source \\
\hline Net total tax GDP ratio & $\begin{array}{l}\text { Annual data from Africa Economic Outlook, Statistical Annex, } \\
\text { April } 2014 .\end{array}$ \\
\hline Net indirect tax GDP ratio & $\begin{array}{l}\text { Annual data from Africa Economic Outlook, Statistical Annex, } \\
\text { April } 2014 .\end{array}$ \\
\hline Net direct tax GDP ratio & $\begin{array}{l}\text { Annual data from Africa Economic Outlook, Statistical Annex, } \\
\text { April } 2014 .\end{array}$ \\
\hline Net trade tax GDP ratio & $\begin{array}{l}\text { Annual Data from Africa Economic Outlook, Statistical Annex, } \\
\text { April } 2014 .\end{array}$ \\
\hline GDP per capita & $\begin{array}{l}\text { Annual data from World Bank, World Development Indicators } \\
\text { (WDI), July } 2013 .\end{array}$ \\
\hline $\begin{array}{l}\text { Debt stock as a percentage of } \\
\text { Gross National Income }\end{array}$ & $\begin{array}{l}\text { Annual data from World Bank, World Development Indicators } \\
\text { (WDI), July } 2013 .\end{array}$ \\
\hline $\begin{array}{l}\text { Share of urban population to } \\
\text { the total population }\end{array}$ & $\begin{array}{l}\text { Annual data from World Bank, World Development Indicators } \\
\text { (WDI), July } 2013 .\end{array}$ \\
\hline $\begin{array}{l}\text { Share of agricultural sector } \\
\text { to GDP }\end{array}$ & $\begin{array}{l}\text { Annual data from World Bank, World Development Indicators } \\
\text { (WDI), July } 2013 .\end{array}$ \\
\hline Trade ratio to GDP & World Bank, World Development Indicators (WDI), July 2013. \\
\hline Aid per capita & $\begin{array}{l}\text { Annual data from World Bank, World Development Indicators } \\
\text { (WDI), July } 2013 .\end{array}$ \\
\hline Consumer Price Index & $\begin{array}{l}\text { Annual and quarterly data from IMF's International Finance } \\
\text { Statistics (IFS), July } 2013 .\end{array}$ \\
\hline Average tariff rate & $\begin{array}{l}\text { Annual data from World Bank, World Development Indicators } \\
\qquad \text { (WDI), July } 2013 .\end{array}$ \\
\hline Average tariff rate squared & We take the square root of the average tariff rate series. \\
\hline Real effective exchange rate & $\begin{array}{l}\text { Annual and quarterly data from IMF's International Finance } \\
\text { Statistics (IFS), July } 2013 .\end{array}$ \\
\hline Voice and Accountability & $\begin{array}{l}\text { Worldwide Governance Indicators, } 2014 . \\
\text { www.govindicators.org }\end{array}$ \\
\hline $\begin{array}{l}\text { Political Stability \& Absence } \\
\text { of Violence/Terrorism }\end{array}$ & $\begin{array}{l}\text { Worldwide Governance Indicators, } 2014 . \\
\text { www.govindicators.org }\end{array}$ \\
\hline Government Effectiveness & $\begin{array}{l}\text { Worldwide Governance Indicators, } 2014 . \\
\text { www.govindicators.org }\end{array}$ \\
\hline Regulatory Quality & $\begin{array}{l}\text { Worldwide Governance Indicators, } 2014 . \\
\text { www.govindicators.org }\end{array}$ \\
\hline Rule of Law & $\begin{array}{l}\text { From Worldwide Governance Indicators, } 2014 . \\
\qquad \text { www.govindicators.org }\end{array}$ \\
\hline
\end{tabular}

improving the efficiency of econometric estimates. Second, panel data has a greater capacity for capturing the complexity of import demand behavior than a single time series data. It is frequently argued that the reason that a researcher finds or does not find certain causal effects in econometric analysis is due to omission of certain variables in one's model specification which are correlated with the included explanatory variables. However, since panel data contain information on both the inter-temporal dynamics and the individuality of the ent- 
ities, it is capable of controlling for the effects of missing or unobserved variables.

Panel data generates more accurate predictions for individual outcomes by pooling the data rather than generating predictions of individual outcomes. If individual behaviors are similar on certain variables, panel data provides the possibility of learning an individual's behavior by observing the behavior of others. Thus, it is possible to obtain a more accurate description of an individual's behavior by supplementing observations of the individual in question with data on other individuals.

\section{Empirical Results}

\subsection{Panel Unit Root Tests}

The first step in the analysis is to establish the order of integration of the variables. We use the [29] panel unit root test and the [30] panel unit root test. The results are reported under Table 2. The results show that the T-bar and the $\mathrm{w}$ (T-bar) test statistic of [30] panel unit root test fail to reject the null hypothesis of presence of unit roots at level for the following variables; total tax to GDP ratio, indirect taxes to GDP ratio, direct taxes to GDP ratio, trade taxes to GDP ratio, average tariff rate, share of agriculture to GDP, share of urban population to the total population and trade ratio to GDP. This suggests that the variables are non-stationary at level.

On the other hand the null hypothesis of presence of unit roots at level for the following variable i.e., inflation, real effective exchange rate, regulatory quality, political stability, aid per capita, control of corruption and rule of law is rejected which suggests that the variables are stationary at level. When the non-stationary variables are transformed into first difference the [30] test reject the null hypothesis of presence of unit roots which implies that the variables are stationary at first difference.

The results of the [30] panel unit root test show that the Modified Chi Squared Pm panel unit root test fail to reject the null hypothesis of presence of unit roots at level for the following variables; total tax to GDP ratio, indirect taxes to GDP ratio, direct taxes to GDP ratio, trade taxes to GDP ratio, average tariff rate, share of agriculture to GDP, share of urban population to the total population and trade ratio to GDP which suggests that the variables are non-stationary at level. When the variables are transformed to first difference the [30] panel unit root test reject the null hypothesis of unit roots. This implies that the variables are stationary at first difference and integrated of $\mathrm{I}(1)$. The other variables i.e., inflation, real effective exchange rate, regulatory quality, political stability, aid per capita, control of corruption and rule of law, implying they are integrated of I(1).

\subsection{Panel Cointegration Test}

We use the Kao panel cointegration tests to examine for presence of cointegration relationship in the variables in the tax functions. The ADF test statistic rejects 
Table 2. Panel unit root test results.

\begin{tabular}{|c|c|c|c|c|}
\hline \multirow[t]{2}{*}{ Variables } & \multicolumn{2}{|c|}{$\begin{array}{l}\text { IPS (2003) panel unit root } \\
\text { test }\end{array}$} & \multirow[t]{2}{*}{$\begin{array}{c}\text { Maddala } \\
\text { and Wu } \\
(1999)\end{array}$} & \multirow[t]{2}{*}{$\begin{array}{c}\text { Order of } \\
\text { integration }\end{array}$} \\
\hline & T-bar & W (T-bar) & & \\
\hline Total tax to GDP & -1.45 & 0.11 & 1.75 & \multirow{2}{*}{$\mathrm{I}(1)$} \\
\hline$\Delta$ Total tax to GDP & $-4.86^{\star}$ & $-4.72^{\star}$ & $17.2^{*}$ & \\
\hline Indirect taxes to GDP & -1.22 & 0.66 & -0.24 & \multirow{2}{*}{$\mathrm{I}(1)$} \\
\hline$\Delta$ Indirect taxes to GDP & $-4.12^{\star}$ & $-4.32^{*}$ & $10.5^{\star}$ & \\
\hline Direct taxes to GDP & -1.43 & 0.48 & 2.11 & \multirow{2}{*}{$\mathrm{I}(1)$} \\
\hline$\Delta$ Direct taxes to GDP & $-5.40^{\star}$ & $-5.2^{*}$ & $22.68^{*}$ & \\
\hline Trade taxes to GDP & -2.69 & -2.04 & 5.33 & \multirow{2}{*}{$\mathrm{I}(1)$} \\
\hline$\Delta$ Trade taxes to GDP & $-5.93^{*}$ & $-5.55^{*}$ & $28.44^{*}$ & \\
\hline Average Tariff Rate & -2.71 & -1.90 & 3.34 & \multirow{2}{*}{$\mathrm{I}(1)$} \\
\hline$\Delta$ Average Tariff Rate & $-6.15^{\star}$ & $-5.28^{*}$ & $13.74^{*}$ & \\
\hline Agricultural share to GDP & 1.30 & 0.33 & 0.65 & \multirow{2}{*}{$\mathrm{I}(1)$} \\
\hline$\Delta$ Agricultural share to GDP & $-4.44^{\star}$ & $-4.63^{*}$ & $11.71^{\star}$ & \\
\hline GDP per capita & $-1.39^{*}$ & $0.27^{*}$ & $20.31^{\star}$ & $\mathrm{I}(0)$ \\
\hline Aid per capita & $-5.31^{\star}$ & $-4.64^{*}$ & $27.24^{\star}$ & $\mathrm{I}(0)$ \\
\hline Trade ratio & -0.62 & 2.24 & 0.02 & \multirow{2}{*}{$\mathrm{I}(1)$} \\
\hline$\Delta$ Trade ratio & $-3.35^{\star}$ & $-3.24^{*}$ & $13.04^{*}$ & \\
\hline $\begin{array}{l}\text { Share of urban population to the } \\
\text { total population }\end{array}$ & -1.34 & 0.80 & -0.59 & \multirow{2}{*}{$\mathrm{I}(1)$} \\
\hline $\begin{array}{l}\Delta \text { Share of urban population to the } \\
\text { total population }\end{array}$ & $1.36^{*}$ & $0.368^{*}$ & $6.64^{*}$ & \\
\hline Real effective exchange rate & -1.271 & 0.543 & $-0.71^{\star}$ & \multirow[t]{2}{*}{$\mathrm{I}(1)$} \\
\hline$\Delta$ Real effective exchange rate & $-0.462^{*}$ & $2.669^{*}$ & $-1.94^{*}$ & \\
\hline Inflation & $-4.585^{\star}$ & $-3.030^{*}$ & $6.42^{*}$ & $\mathrm{I}(0)$ \\
\hline Regulatory quality & $-5.37^{\star}$ & $-5.12^{*}$ & $8.54^{*}$ & $\mathrm{I}(0)$ \\
\hline Political stability & $-6.40^{\star}$ & $-4.45^{\star}$ & $31.06^{\star}$ & $\mathrm{I}(0)$ \\
\hline Control of corruption & $-4.07^{\star}$ & $-4.12^{*}$ & $34.43^{\star}$ & $\mathrm{I}(0)$ \\
\hline Accountability & $-5.66^{\star}$ & $-4.98^{\star}$ & $-0.59^{\star}$ & $\mathrm{I}(0)$ \\
\hline Rule of Law & $-3.33^{\star}$ & $-2.54^{\star}$ & $1.19^{*}$ & $\mathrm{I}(0)$ \\
\hline
\end{tabular}

Note: In the specification of the tests above, we use constant and trend as the deterministic terms. We use one lag for total tax to GDP ratio, indirect taxes to GDP ratio, direct taxes to GDP ratio, trade taxes to GDP ratio, average tariff rate, share of agriculture to GDP, share of urban population to the total population and trade ratio to GDP for the IPS and Maddala and $\left.\mathrm{Wu} .{ }^{*}\right)$ denotes rejection of the null hypothesis at $1 \%$.

the null hypothesis of no cointegration at 1 percent level of significance for the variables in the four tax functions. This implies that there exists a long-run relationship in the variables in the tax functions.

\subsection{Panel Cointegration Regressions}

The results from the panel unit roots test and the panel cointegration tests show that the variables across the four tax models are integrated of $\mathrm{I}(0)$ and $\mathrm{I}(1)$ but 
also cointegrated. According to [31] and [32] the asymptotics of large T, large $\mathrm{N}$ panels are different from the asymptotics of small $\mathrm{T}$ and small $\mathrm{N}$ panels. Therefore estimations for small $\mathrm{T}$ and small $\mathrm{N}$ panels rely on Fixed or Random effects estimator if the variables are integrated of the same order and also cointegrated. On the other hand if the variables are not integrated of the same order and or cointegrated, the small $\mathrm{T}$ and small $\mathrm{N}$ panels rely on the Fully-Modified Ordinally Least Squares (FMOLS) and Dynamic Ordinally Least Squares (DOLS). Estimations for small $\mathrm{T}$ and large $\mathrm{N}$ panels rely on a combination of fixed effects estimators and instrumental variable estimators, such as the [1]. Reference [33] generalized method-of-moments estimator. The large $\mathrm{N}$ and large $\mathrm{T}$ panel estimations, rely on the mean-group (MG) and pooled mean-group (PMG) estimators [31].

In our specific case i.e., $\mathrm{T}=19$ and $\mathrm{N}=5$. We have a relatively small $\mathrm{T}$ and small $\mathrm{N}$ panel that is integrated of $\mathrm{I}(0)$ and $\mathrm{I}(1)$ but cointegrated. From the literature we adopt the FMOLS and DOLS estimators. Reference [31] shows that the FMOLS and DOLS estimators performs well in small samples. The FMOL and DOLS model is considered superior to other estimation techniques because it inherently correct for endogeneity, serial correlation and asymptotic bias.

\subsection{Discussion of Empirical Results}

Table 3 shows the empirical results of the FMOLS and DOLS tax models. The models presented include; total tax, indirect taxes, direct taxes and trade taxes. The results from the regression estimation reveal the following findings. The coefficient for the average tariff rate that is used as a measure for trade openness is positive and statistically significant with respect to total tax, indirect and trade tax but insignificant for direct taxes. The positive results implies that when tariff are increased, total taxes, indirect taxes and trade taxes also increases. Next we examine the sign of the coefficient of average tariff rate squared to test if the Laffer curve effect exists for total taxes, indirect taxes and trade taxes.

The results show that the sign of the coefficient of average tariff rate squared is negative and statistically significant for total tax, indirect and trade tax but insignificant for direct taxes. This illustrate the expected "Laffer effect" i.e., the tax-maximizing tariff rate. Therefore, for countries in this panel the tax maximizing tariff rate is estimated at approximately 9.2 percent for total tax, 12.2 percent for indirect tax and 14 percent for trade taxes for the period 1994 to 2012. Thus, for countries in this group, an increase in tariff rates beyond these rate would result into a decrease in revenue for the three tax categories. The results are expected and are similar to findings from previous studies such as [20] who show that the increase in tariff rate can only increase tax revenue up to a certain rate thereafter tax revenue decreases.

In Table 4 we control for the results of the average tariff rate variable by introducing another measure for trade openness i.e., the trade ratio to GDP. The results from this measure show that with respect to total tax, indirect, direct and trade tax models, the coefficient for trade ratio to GDP is positive and statistically 
Table 3. FMOL and DOLS tax models using average tariff rate.

\begin{tabular}{|c|c|c|c|c|c|c|c|c|}
\hline & (1) & (2) & (3) & (4) & (5) & (6) & (7) & (8) \\
\hline \multirow[t]{2}{*}{ VARIABLES } & $\begin{array}{c}\text { Total tax/ } \\
\text { GDP }\end{array}$ & $\begin{array}{l}\text { Total tax/ } \\
\text { GDP }\end{array}$ & $\begin{array}{c}\text { Direct } \\
\operatorname{tax} / G D P\end{array}$ & $\begin{array}{c}\text { Direct } \\
\operatorname{tax} / G D P\end{array}$ & $\begin{array}{c}\text { Indirect } \\
\operatorname{tax} / G D P\end{array}$ & $\begin{array}{c}\text { Indirect } \\
\operatorname{tax} / G D P\end{array}$ & $\begin{array}{c}\text { Trade } \\
\text { taxes/GDP }\end{array}$ & $\begin{array}{c}\text { Trade } \\
\text { taxes/GDP }\end{array}$ \\
\hline & FMOL & DOLS & FMOL & DOLS & FMOL & DOLS & FMOL & DOLS \\
\hline \multirow[t]{2}{*}{ Urban Population } & $0.307^{*}$ & $0.296^{*}$ & $0.297^{*}$ & $0.342^{*}$ & 0.066 & $0.087^{*}$ & $0.187^{*}$ & $0.156^{* *}$ \\
\hline & $(0.070)$ & $(0.09)$ & $(0.064)$ & $(0.067)$ & $(0.055)$ & $(0.062)$ & $(0.073)$ & $(0.076)$ \\
\hline \multirow[t]{2}{*}{ GDP per capita } & $2.51^{*}$ & $1.854^{*}$ & -0.574 & $-0.663^{\star * *}$ & $0.633^{\star *}$ & $0.642^{* *}$ & $0.784^{* *}$ & 0.501 \\
\hline & $(0.46)$ & $(0.519)$ & $(0.387)$ & $(0.376)$ & $(0.330)$ & $(0.343)$ & $(0.441)$ & $(0.448)$ \\
\hline \multirow[t]{2}{*}{ Debt/GNI } & $-0.510^{\star *}$ & $-0.140^{\star \star}$ & -0.063 & -0.058 & $-0.209^{\star}$ & $-0.219^{*}$ & $0.540^{\star}$ & $0.138^{* *}$ \\
\hline & $(0.06)$ & $(0.074)$ & $(0.055)$ & $(0.053)$ & $(0.047)$ & $(0.049)$ & $(0.059)$ & $(0.052)$ \\
\hline \multirow[t]{2}{*}{ Foreign aid } & $0.15^{\star *}$ & 0.282 & -0.208 & 0.232 & 0.105 & 0.124 & 0.241 & 0.178 \\
\hline & $(0.207)$ & $(0.264)$ & $(0.172)$ & $(0.191)$ & $(0.147)$ & $(0.175)$ & $(0.197)$ & $(0.211)$ \\
\hline \multirow[t]{2}{*}{ Exchange rate } & $-1.388^{*}$ & $-1.433^{*}$ & $-0.981^{*}$ & $-0.638^{* *}$ & $-1.157^{\star}$ & $-1.069^{*}$ & $1.073^{*}$ & $0.895^{\star *}$ \\
\hline & $(0.412)$ & $(0.475)$ & $(0.343)$ & $(0.344)$ & $(0.292)$ & $(0.314)$ & $(0.393)$ & $(0.395)$ \\
\hline \multirow[t]{2}{*}{ ATR } & $0.180^{* * *}$ & 0.085 & 0.017 & 0.013 & $0.151^{\star}$ & $0.104^{\star *}$ & $0.350^{* *}$ & $0.343^{* *}$ \\
\hline & $(0.093)$ & $(0.083)$ & $(0.078)$ & $(0.060)$ & $(0.066)$ & $(0.055)$ & $(0.178)$ & $(0.181)$ \\
\hline \multirow[t]{2}{*}{ ATR squared } & $-0.97^{\star * *}$ & -0.464 & -0.295 & -0.229 & $-0.066^{\star *}$ & $-0.425^{\star \star}$ & $-0.012^{\star *}$ & -0.012 \\
\hline & $(0.510)$ & $(0.471)$ & $(0.425)$ & $(0.341)$ & $(0.362)$ & $(0.311)$ & $(0.070)$ & $(0.007)$ \\
\hline \multirow[t]{2}{*}{ Inflation } & $-0.028^{\star}$ & $-0.023^{\star}$ & $-0.127^{\star}$ & $-0.014^{\star \star}$ & $-0.013^{\star}$ & 0.010 & 0.007 & 0.067 \\
\hline & $(0.008)$ & $(0.008)$ & $(0.006)$ & $(0.006)$ & $(0.001)$ & $(0.006)$ & $(0.011)$ & $(0.048)$ \\
\hline \multirow[t]{2}{*}{ Agriculture } & $-0.005^{\star *}$ & $-0.051^{\star *}$ & $-0.023^{\star *}$ & -1.016 & -0.010 & -0.004 & -0.014 & -0.09 \\
\hline & $(0.017)$ & $(0.019)$ & $(0.014)$ & $(0.014)$ & $(0.012)$ & $(0.013)$ & $(0.017)$ & $(0.018)$ \\
\hline \multirow[t]{2}{*}{$\begin{array}{c}\text { Government effective- } \\
\text { ness }\end{array}$} & $-2.365^{*}$ & $-2.002^{\star}$ & 0.213 & -0.335 & -0.047 & -0.167 & -0.590 & -0.856 \\
\hline & $(0.613)$ & $(0.735)$ & $(0.510)$ & $(0.533)$ & $(0.434)$ & $(0.486)$ & $(0.578)$ & $(0.644)$ \\
\hline \multirow[t]{2}{*}{ Rule of law } & -0.136 & 0.278 & 0.543 & $1.055^{*}$ & 0.134 & $0.315^{\star}$ & $-1.581^{*}$ & $-1.276^{\star *}$ \\
\hline & $(0.558)$ & $(0.714)$ & $(0.464)$ & $(0.518)$ & $(0.395)$ & $(0.472)$ & $(0.523)$ & $(0.032)$ \\
\hline \multirow[t]{2}{*}{ Political Stability } & 0.065 & -0193 & $-0.560^{\star *}$ & $-0.420^{* *}$ & -0.151 & -0.193 & 0.200 & 0.253 \\
\hline & $(0.340)$ & $(0.317)$ & $(0.283)$ & $(0.230)$ & $(0.241)$ & $(0.210)$ & $(0.323)$ & $(0.270)$ \\
\hline \multirow[t]{2}{*}{ Regulatory Quality } & -0.395 & -0.328 & $-1.024^{\star *}$ & -0.903 & $-2.271^{\star}$ & $-1.942^{\star *}$ & -0.201 & -0.060 \\
\hline & $(0.634)$ & $(0.798)$ & $(0.528)$ & $(0.579)$ & $(0.449)$ & $(0.527)$ & $(0.567)$ & $(0.629)$ \\
\hline \multirow[t]{2}{*}{ Control of corruption } & $1.555^{*}$ & $1.221^{*}$ & 0.493 & 0.275 & $1.397^{*}$ & $1.258^{\star *}$ & 1.033 & $0.834^{* *}$ \\
\hline & $(0.410)$ & $(0.470)$ & $(0.341)$ & $(0.341)$ & $(0.290)$ & $(0.311)$ & $(0.350)$ & $(0.368)$ \\
\hline R-squared & 94.3 & 94.3 & 93.1 & 92.8 & 0.822 & 83.8 & 73.0 & 73.4 \\
\hline
\end{tabular}

Note: Standard errors in parentheses ${ }^{*} \mathrm{p}<0.01,{ }^{* *} \mathrm{p}<0.05,{ }^{* *} \mathrm{p}<0.1$. The dependent variable for Models (1) and (2) is total tax of GDP ratio, (3) and (4) direct tax to GDP ratio (5) and (6) indirect tax to GDP ratio while (7) and (8) is trade tax to GDP ratio.

significant. This implies that the trade ratio to GDP positively influences the four categories of tax. The result imply that trade openness leads to a growth in taxes for the four tax categories. The positive relationship is in line with findings from previous studies such as [8] and [21] these studies show that openness has a positive relationship with tax. From the result, we can conclude that an increase trade openness increases tax for countries in this group. 
M. S. Gaalya et al.

Table 4. FMOL and DOLS tax models using trade ratio to GDP.

\begin{tabular}{|c|c|c|c|c|c|c|c|c|}
\hline & (1) & (2) & (3) & (4) & (5) & (6) & (7) & (8) \\
\hline \multirow[t]{2}{*}{ VARIABLES } & $\begin{array}{c}\text { Total tax/ } \\
\text { GDP }\end{array}$ & $\begin{array}{c}\text { Total tax/ } \\
\text { GDP }\end{array}$ & $\begin{array}{c}\text { Direct } \\
\text { tax/GDP }\end{array}$ & $\begin{array}{c}\text { Direct } \\
\text { tax/GDP }\end{array}$ & $\begin{array}{l}\text { Indirect } \\
\text { tax/GDP }\end{array}$ & $\begin{array}{l}\text { Indirect } \\
\text { tax/GDP }\end{array}$ & $\begin{array}{c}\text { Trade } \\
\text { taxes/GDP }\end{array}$ & $\begin{array}{c}\text { Trade } \\
\text { taxes/GDP }\end{array}$ \\
\hline & FMOL & DOLS & FMOL & DOLS & FMOL & DOLS & FMOL & DOLS \\
\hline \multirow[t]{2}{*}{ Urban Population } & 0.0329 & -0.00408 & 0.00159 & 0.0156 & -0.0024 & -0.0361 & 0.0493 & 0.0704 \\
\hline & $(0.0385)$ & $(0.0647)$ & $(0.0408)$ & $(0.0702)$ & $(0.0227)$ & $(0.0411)$ & $(0.0333)$ & $(0.0700)$ \\
\hline \multirow[t]{2}{*}{ GDP per capita } & $2.290^{*}$ & $2.183^{*}$ & $1.393^{*}$ & $1.805^{\star}$ & $0.769^{*}$ & $0.765^{\star *}$ & $-0.576^{*}$ & $-1.113^{\star *}$ \\
\hline & $(0.233)$ & $(0.505)$ & $(0.247)$ & $(0.549)$ & $(0.138)$ & $(0.321)$ & $(0.202)$ & $(0.547)$ \\
\hline \multirow[t]{2}{*}{ Debt/GNI } & -0.0851 & -0.179 & -0.0119 & 0.130 & $-0.0961^{\star *}$ & 0.0224 & $0.172^{*}$ & 0.149 \\
\hline & $(0.0647)$ & $(0.181)$ & $(0.0685)$ & $(0.197)$ & $(0.0382)$ & $(0.115)$ & $(0.0561)$ & $(0.196)$ \\
\hline \multirow[t]{2}{*}{ Foreign aid } & 0.172 & $0.756^{* * *}$ & -0.0226 & -0.0769 & 0.00766 & 0.0388 & 0.211 & 0.579 \\
\hline & $(0.232)$ & $(0.426)$ & $(0.246)$ & $(0.463)$ & $(0.137)$ & $(0.271)$ & $(0.201)$ & $(0.461)$ \\
\hline \multirow[t]{2}{*}{ Exchange rate } & $-0.22^{* * *}$ & $-0.511^{* * *}$ & $-0.385^{\star}$ & -0.492 & $-0.129^{* * *}$ & -0.118 & $0.613^{*}$ & $0.871^{\star}$ \\
\hline & $(0.126)$ & $(0.277)$ & $(0.133)$ & $(0.300)$ & $(0.0744)$ & $(0.176)$ & $(0.109)$ & $(0.299)$ \\
\hline \multirow[t]{2}{*}{ Trade ratio to GDP } & $0.0390^{*}$ & $0.0513^{* * *}$ & $0.028^{*}$ & $0.010^{\star}$ & $0.0268^{\star}$ & $0.0396^{* *}$ & $0.016^{*}$ & $0.015^{\star}$ \\
\hline & $(0.0109)$ & $(0.0274)$ & $(0.008)$ & $(0.006)$ & $(0.00646)$ & $(0.0174)$ & $(0.007)$ & $(0.006)$ \\
\hline \multirow[t]{2}{*}{ Inflation } & -0.0140 & 0.00407 & -0.0155 & -0.0142 & -0.0106 & -0.00652 & 0.007 & 0.067 \\
\hline & $(0.0127)$ & $(0.0445)$ & $(0.0135)$ & $(0.0483)$ & $(0.00750)$ & $(0.0283)$ & $(0.011)$ & $(0.048)$ \\
\hline \multirow[t]{2}{*}{ Agriculture } & $-0.095^{\star}$ & -0.0691 & $-0.0676^{\star}$ & $-0.105^{* * *}$ & $-0.0374^{\star}$ & -0.0438 & -0.0221 & -0.0523 \\
\hline & $(0.0205)$ & $(0.0528)$ & $(0.0217)$ & $(0.0574)$ & $(0.0121)$ & $(0.0336)$ & $(0.0177)$ & $(0.0572)$ \\
\hline \multirow[t]{2}{*}{$\begin{array}{l}\text { Government } \\
\text { effectiveness }\end{array}$} & $-3.606^{\star}$ & $-4.571^{\star *}$ & -0.870 & -0.186 & -0.566 & -0.0779 & -0.431 & 0.657 \\
\hline & $(0.803)$ & $(1.832)$ & $(0.851)$ & $(1.990)$ & $(0.474)$ & $(1.163)$ & $(0.696)$ & $(1.983)$ \\
\hline \multirow[t]{2}{*}{ Rule of law } & -0.846 & -0.205 & -0.851 & -0.699 & 0.100 & -0.286 & -0.411 & -2.327 \\
\hline & $(0.801)$ & $(1.768)$ & $(0.849)$ & $(1.921)$ & $(0.473)$ & $(1.123)$ & $(0.694)$ & $(1.913)$ \\
\hline \multirow[t]{2}{*}{ Political Stability } & 0.286 & 0.625 & -0.0123 & -0.281 & -0.162 & 0.220 & -0.112 & 0.533 \\
\hline & $(0.355)$ & $(0.837)$ & $(0.376)$ & $(0.909)$ & $(0.210)$ & $(0.532)$ & $(0.308)$ & $(0.906)$ \\
\hline \multirow[t]{2}{*}{ Regulatory Quality } & $1.585^{\star}$ & $2.365^{\star *}$ & -0.146 & -1.356 & -0.417 & -0.626 & $1.196^{*}$ & $1.944^{*}$ \\
\hline & $(0.482)$ & $(1.056)$ & $(0.511)$ & $(1.148)$ & $(0.285)$ & $(0.671)$ & $(0.418)$ & $(1.143)$ \\
\hline $\begin{array}{l}\text { Control of } \\
\text { corruption }\end{array}$ & $1.419^{*}$ & $1.709^{* *}$ & 0.554 & 0.701 & $0.777^{\star}$ & 0.722 & -0.0427 & -0.478 \\
\hline Inflation & $(0.352)$ & $(0.723)$ & $(0.372)$ & $(0.786)$ & $(0.208)$ & $(0.459)$ & $(0.305)$ & $(0.783)$ \\
\hline R-squared & 0.843 & 0.966 & 0.615 & 0.912 & 0.686 & 0.906 & 0.555 & 0.781 \\
\hline
\end{tabular}

Note: Standard errors in parentheses ${ }^{*} p<0.01,{ }^{* *} p<0.05,{ }^{* * *} p<0.1$. The dependent variable for Models (1) and (2) is total tax of GDP ratio, (3) and (4) direct tax to GDP ratio (5) and (6) indirect tax to GDP ratio while (7) and (8) is trade tax to GDP ratio.

The results from other variables used in the tax functions show that the coefficient for the ratio of urban population to total population is positive and statistically significant with respect to total taxes, direct tax and trade taxes but insignificant for indirect taxes. The result implies that an increase in urban population increases total tax, direct taxes and trade taxes. Therefore an increase in the urban population is expected to increase total taxes, direct tax and trade taxes for this group of countries. The result is expected and it's in line with study findings 
by [11] who show that urbanization increase total taxes, direct tax and trade taxes for developing countries.

The coefficient for GDP per capita is positive and statistically significant across the four tax categories. This suggests that an increase in GDP per capita increases total tax, indirect tax, direct tax and trade tax. The positive relationship between GDP per capita and tax suggests that a high level of development are associated with a higher ability for tax payers to pay taxes. This is accounted for by the fact that because income levels are so low in this group of countries, higher income facilitates increased trade and thus higher trade tax. This result is expected and it is in line with a study by [28] who that found that the capacity to collect and pay taxes increases with the level of development

The coefficient for debt stock as a percentage of gross national income is negative and statistically significant with respect to total tax, direct tax and trade tax. The results shows that the debt stock as a percentage of gross national income is an important determinant of tax. The result suggests that an increase in debt decreases total tax, direct tax, indirect tax and trade tax for this group of countries. This result is expected and shows that an increase in debt decreases the tax base for the three tax categories. The results are similar to findings by [3] and [34] who show that government debt decreases tax performance in developing countries.

The coefficient for foreign aid is positive and statistically significant with respect to total tax but insignificant for direct, indirect and trade taxes. This implies that foreign aid increases total tax. The result is supported by [3] who pointed out that if foreign aid comes primarily in the form of loans, then the burden of future loan repayments may induce policymakers to mobilize higher taxes. For countries in this group a large part of foreign aid is in form of concessional and non-concessional loan that attract interest. This result is expected and it's in line with previous studies such as [34] and [35] who find that foreign aid leads to an increase in tax performance for low income countries.

The coefficient for inflation and real effective exchange rate are negative and statistically significant with respect to total tax, direct tax and indirect tax. The results implies that an increase in inflation and real effective exchange rate decreases tax performance. This result is expected and it's similar to findings from previous studies such as [36]. The real effective exchange rate and inflation, suggest that real exchange rate appreciation and higher inflation depress revenues, which is consistent with Tanzi's hypotheses. The hypothesis observes that there is often an inverse relationship between a country's tax revenue and the real level of its official exchange rate.

The results on coefficient for the share of agriculture sector to GDP is negative and statistically significant with respect to total tax and direct taxes. For example, a one percent increase in the share of agriculture sector could reduce revenue performance by as much as 0.4 percent. The result implies that the agriculture sector decreases tax from both tax categories. The possible explanation for this result is that the agriculture sector has small farmers that are notoriously difficult to tax and the sector does not generate large taxable surplus. In addition 
many low income countries are unwilling to tax the agriculture sector because the agriculture sector provides food and livelihood for a larger part of the population. The negative relationship is expected and is consistent with studies by [3] [26] [37] who show that in developing countries the agriculture sector negatively influences tax.

The results on the governance indicators are mixed, the coefficient for rule of law has a negative and statistically significant relationship with respect to trade taxes. This implies that rule of law negatively influences trade tax in this group of countries. The variable rule of law reflects perceptions of the extent to which agents have confidence in and abide by the rules of society, and in particular the quality of contract enforcement, property rights, the police, and the courts, as well as the likelihood of crime and violence. The result suggest the group of countries need to improve their rule of law as a means of growing trade taxes.

The coefficient of regulatory quality is negative and statistically significant with respect to indirect taxes and direct taxes. The result implies that the regulatory quality in EAC countries decreases indirect and direct taxes. The variable regulatory quality reflects perceptions of the ability of the government to formulate and implement sound policies and regulations that permit and promote private sector development. The negative relationship between regulatory quality and the two tax categories suggests that EAC countries need to undertake regulatory reforms to improve indirect taxes and direct taxes. The reforms could relate to the ease of doing business as well as harmonization of service delivery by government institutions.

The coefficient for political stability shows a negative and statistically significant relationship with respect to indirect tax. The variable political stability reflects perceptions of the likelihood that the government will be destabilized or overthrown by unconstitutional or violent means, including politically-motivated violence and terrorism. This result suggest that indirect taxes in the EAC countries are negatively affected by political stability. This result is supported by [3] who shows that a stable economy facilitates growth in revenue for low income countries.

The coefficient of control of corruption is positive and statistically significant with respect to trade taxes and indirect taxes. A reduction in corruption (implying an increase in the corruption index) would substantially increase trade taxes and indirect taxes. The result implies that the control of corruption increases trade taxes and indirect taxes. The variable control of corruption reflects perceptions of the extent to which public power is exercised for private gain, including both petty and grand forms of corruption, as well as "capture" of the state by elites and private interests. The positive result suggests that control of corruption in EAC countries could improve indirect and trade tax performance.

\section{Conclusions and Policy Recommendations}

\subsection{Conclusions}

Despite the well-known gains from trade, the effects of trade openness are a pri- 
ori ambiguous. For this reason, it's important to establish effects of trade openness on different sources of government revenue for any country opening its borders to trade. This study establishes the effects of trade openness on direct, indirect, trade as well as total tax revenue. A panel data cointegration technique that uses the Fully Modified Ordinally Least Squares and Dynamic Ordinally Least Squares was employed. The data are annual cross country panels of East Africa countries covering the period 1994-2012. The data were obtained from the IMF's International Finance Statistics, the African Development Bank's African Economic Outlook and the World Bank's World Development Indicators and the World Governance Indicators, which is an important contribution of the paper to trade openness literature.

After testing for robustness of the results, our main findings show that the tariff rate positively influences total tax, indirect and trade taxes but the relationship between the tariff rate and direct taxes is found to be insignificant. The sign of the coefficient of average tariff rate squared is negative and statistically significant for total tax, indirect and trade tax. The results illustrate the expected "Laffer effect" i.e., the tax-maximizing tariff rate. The tax maximizing tariff rate is estimated at approximately 9.2 percent for total tax, 12.2 percent for indirect tax and 14 percent for trade taxes for the countries in this panel. Thus, for countries in this group, an increase in tariff rates beyond these rates would result into a decrease in revenue for the three tax categories.

In addition to the trade openness variable, the following variable are found to positively influence taxes in EAC countries, including average tariff rate, trade ratio to GDP, GDP per capita, the ratio of urban population to total population, foreign aid and control of corruption. While the following variables are found to negatively influence tax performance i.e., debt stock as a percentage of gross national income, inflation, real effective exchange rate, share of agriculture sector to GDP, regulatory quality, political stability and rule of law.

\subsection{Policy Recommendations}

The policy implication is that governments of EAC countries should implement trade openness policies, particularly reducing of the tariff rate to help in improving tax revenue performance.

\section{Acknowledgements}

I acknowledge work by Micah Samuel Gaalya (2015) who previously focused on Trade liberalization and tax revenue performance in Uganda. This study extends the study by using a more robust estimation technique the Fully Modified Ordinally Least Squares and Dynamic Ordinally Least Squares for selected East African Countries.

\section{References}

[1] World Bank (2012) Revenue to GDP Ratio, Atlas Method [Data File]. http://data.worldbank.org/indicator/GC.TAX.TOTL.GD.ZS?view=chart 
[2] World Trade Organization (2013) World Trade Report, Geneva, Switzerland. https://www.wto.org/english/res_e/booksp_e/wtr13-2b_e.pdf

[3] Gupta, A. (2007) Determinants of Revenue Efforts in Developing Countries. IMF Working Papers, 1-39. https://doi.org/10.5089/9781451867480.001

[4] Frankel, J.A. and Romer, D. (1999) Does Trade Cause Growth? American Economic Review, 89, 379-399.

[5] Barro, R.J. (1994) Democracy \& Growth (No. w4909). National Bureau of Economic Research, Massachusetts.

[6] Blejer, M. and Cheasty, A. (1990) Fiscal Implications of Trade Liberalization. In: Tanzi, V., Ed., Fiscal Policy in Open Developing Economies, International Monetary Fund, Washington DC, 66-81.

[7] Tanzi, V. (1989) The Impact of Macroeconomic Policies on the Level of Taxation and the Fiscal Balance in Developing Countries. IMF Staff Papers, 36, 633-656. https://doi.org/10.2307/3867050

[8] Ebrill, L., Gropp, R.E. and Stotsky, J. (1999) Revenue Implications of Trade Liberalization (Vol. 180). IMF Occasional Papers, No. 180.

[9] Rodríguez, F. and Rodrik, D. (1999) Trade Policy and Economic Growth: A Skeptic's Guide to the Cross-National Literature. NBER Working Paper 7081.

[10] Peters, A., Secretariat, C.A.R.I.C.O.M. and Guyana, S.A. (2002) The Fiscal Effects of Tariff Reduction in the Caribbean Community. Unpublished.

[11] Khattry, B. and Rao, J.M. (2002) Fiscal Faux Pas? An Analysis of the Revenue Implications of Trade Liberalization. World Development, 30, 1431-1444.

https://doi.org/10.1016/S0305-750X(02)00043-8

[12] McIntyre, M.A. (2005) Trade Integration in the East African Community: An Assessment for Kenya (No. 05/143). International Monetary Fund, Washington DC.

[13] Teera, J.M. (2003) Could Do Better: An Appraisal of Uganda's Tax Performance Relative to Sub-Saharan Africa.

http://citeseerx.ist.psu.edu/viewdoc/download?doi=10.1.1.111.1741\&rep=rep1\&type $=\mathrm{pdf}$

[14] Hisali, E. (2012) Trade Policy Reform and International Trade Revenue in Uganda. Economic Modelling, 29, 2144-2154. https://doi.org/10.1016/j.econmod.2012.06.033

[15] Addison, T. and Levin, J. (2006) Tax Policy Reform in Developing Countries.

[16] Tanzi, V. (1987) Quantitative Characteristics of the Tax Systems of Developing Countries. In: Newberry, D. and Stern, N.H., Eds., The Theory of Taxation for Developing Countries, Oxford University Press for the World Bank, New York, 205241.

[17] Baunsgaard, T. and Keen, M. (2009) Revenue and (or?) Trade Liberalization. IMF Working Paper 2005-112. Journal of Public Economics, 94, 563-577. https://doi.org/10.1016/j.jpubeco.2009.11.007

[18] Othieno, L. and Shinyekwa, I. (2011) Trade, Revenue and Welfare Effects of The East African Community Customs Union Principle of Asymmetry on Uganda: An Application of Wits-Smart Simulation Model. Economic Policy Research Centre (EPRC), Research Series 150480.

[19] Tanzi, M.V. (1997) The Changing Role of the State in the Economy: A Historical Perspective (No. 97-114). International Monetary Fund, Washington DC.

[20] Laffer, A.B. (2004) The Laffer Curve: Past, Present, and Future. Backgrounder 1765. Heritage Foundation, Washington DC.

[21] Agbeyegbe, T.D., Stotsky, J. and WoldeMariam, A. (2006) Trade Liberalization, 
Exchange Rate Changes, and Revenue in Sub-Saharan Africa. Journal of Asian Economics, 17, 261-284. https://doi.org/10.1016/j.asieco.2005.09.003

[22] Fisman, R. and Wei, S.J. (2004) Tax Rates and Tax Evasion: Evidence from "Missing Imports" in China. Journal of Political Economy, 112, 471.

https://doi.org/10.1086/381476

[23] Aizenman, J. and JinJarak, Y. (2009) Globalisation and Developing Countries-A Shrinking Tax Base? Journal of Development Studies, 45, 653-671. https://doi.org/10.1080/00220380802582338

[24] Glenday, G. (2002) Trade Liberalization and Customs Revenue: Does Trade Liberalization Lead to Lower Customs Revenue? The Case of Kenya. Journal of African Finance and Economic Development, 5, 89-125.

[25] Stotsky, J.G. and WoldeMariam, A. (1997) Tax Effort in Sub-Saharan Africa (No. 97/107). International Monetary Fund, Tanzi.

[26] Bahl, R.W. (1972) Alternative Methods for Revenue Forecasting in Developing Countries: A Conceptual Analysis. IMF Unpublished Paper.

[27] Lotz, J.R. and Morss, E.R. (1970) A Theory of Tax Level Determinants for Developing Countries. Economic Development and Cultural Change, 18, 328-341. https://doi.org/10.1086/450436

[28] Chelliah, R.J. (1971) Trends in Taxation in Developing Countries. IMF Staff Papers, 18, 254-325. https://doi.org/10.2307/3866272

[29] Maddala, G.S. and Wu, S. (1999) A Comparative Study of Unit Root Tests with Panel. Data and a New Simple Test. Oxford Bulletin of Economics and Statistics, 61, 631-652. https://doi.org/10.1111/1468-0084.61.s1.13

[30] Pesaran, M.H. (2007) A Simple Panel Unit Root Test in the Presence of Cross-Section Dependence. Journal of Applied Econometrics, 22, 265-312. https://doi.org/10.1002/jae.951

[31] Baltagi, B.H. (2005) Econometric Analysis of Panel Data. 3rd Edition.

[32] Pedroni, P. (2004) Panel Cointegration: Asymptotic and Finite Sample Properties of Pooled Time Series Tests with an Application to the PPP Hypothesis. Econometric Theory, 20, 597-625. https://doi.org/10.1017/S0266466604203073

[33] Arellano, M. and Bond S. (1991) Some Tests of Specification for Panel Data: Monte Carlo Evidence and an Application to Employment Equations. Review of Economic Studies, 38, 277-297. https://doi.org/10.2307/2297968

[34] Brautigam, D. (2000) Aid Dependence and Governance. Almqvist \& Wiksell International, Stockholm.

[35] Maren, M. (1997) The Road to Hell: The Ravaging Effects of Foreign Aid and International Charity. World and I, 12, 264-271.

[36] Pritchett, P. and Zisserman, A. (1998) Wide Baseline Stereo Matching. IEEE Sixth International Conference on Computer Vision, Bombay, 4-7 January 1998, 754-760. https://doi.org/10.1109/ICCV.1998.710802

[37] Tanzi, V. and BIejer, M.I. (1988) Public Debt and Fiscal Policy in Developing Countries. In: Arrow, K.J. and Michael, J.B., Eds., The Economics of Public Debt, International Economic Association, Macmillan Press, London. 
Submit or recommend next manuscript to SCIRP and we will provide best service for you:

Accepting pre-submission inquiries through Email, Facebook, LinkedIn, Twitter, etc. A wide selection of journals (inclusive of 9 subjects, more than 200 journals)

Providing 24-hour high-quality service

User-friendly online submission system

Fair and swift peer-review system

Efficient typesetting and proofreading procedure

Display of the result of downloads and visits, as well as the number of cited articles Maximum dissemination of your research work

Submit your manuscript at: http://papersubmission.scirp.org/

Or contact me@scirp.org 